\title{
THE INFLUENCE OF THE THERMOPLASTIC RINFORCEMENT TAPE LOCATION ON THE SEAM PERFORMANCE
}

Saška Golomeova ${ }^{1 *}$, Goran Demboski ${ }^{2}$

(PROFESSIONAL PAPER)

UDC 687.053.665:677.074.33

${ }^{1}$ Faculty of Technology, University "Goce Delčev"- Štip, Macedonia

2 Faculty of Technology and Metallurgy, University "Ss. Cyril and Methodius"- Skopje, Macedonia

The aim of this paper is to investigate the influence of a thermoplastic stitched reinforced tape location in the seam, on seam slippage, seam strength and seam efficiency. Seam samples without reinforcement and reinforced with a fused tape were prepared. All the samples were prepared with $1.2 \mathrm{~cm}$ seam allowance. The samples reinforced with fusible tapes were produced using three positions of the fixing fusible tape. The obtained results have shown that, with the insertion of the thermoplastic stitched reinforced tape in the seam structure, the seam strength and efficiency are generally increased, while the seam slippage decreased. In all investigated cases it was found that the difference in the reinforced tape position in the seam influences the seams performance.
Keywords: garment seams, fusible reinforced stitched tape, seam construction

\section{Introduction}

Great international competition forces companies to make efforts and difference to keep old clients and attract new ones. To remain competitive, garment companies are mainly oriented towards the increasing productivity providing additional services, increasing the product added value and increasing the quality. The garment seams performance is the feature that greatly contributes to the overall garment quality. In cases where a clothing company is not involved in fabric purchasing and the fabric is supplied by the client, the problems can arise at the production stage regarding the seam quality. This kind of problems should be addressed quickly and efficiently [1-3].

Seam slippage, the seam strength and the seam efficiency are the seam quality criteria which define the seam stability. Therefore, achieving the satisfactory seam strength and seam slippage resistance is of great importance for the overall seams quality in the garment product development [4-6]. In everyday use, garments are normally subjected to loads less than those required for rupturing the seam but which may be sufficient to slip one yarn system over the other in the fabric $[7,8]$. As a result of yarn slippage, an opening appears near the seam [9]. This phenomenon occurs before seam rupturing which can be the result of fabric breaks, thread breaks or both. The seam strength refers to the load required to break a seam. The seam efficiency is expressed as the ratio of seam and the fabric strength [10]. The seam efficiency measures durability along the seam line [11]. The investigation of techniques to reduce the seam slippage and increase the seam strength and seam efficiency in the garment during the production process is very important for the development of high quality textile products. Many studies have been performed, but this question is still open [12 -16]. For this purpose, we used a stitched reinforced tape for the fabric structure strengthening in the sewing area and we investigated the influence of a thermoplastic stitched reinforced tape location in the seam, on the seam slippage, seam strength and seam efficiency.

\section{Experimental}

Three lightweight woven fabrics for ladies blouses were used. The characteristics of fabrics used are given in Table 1. The surface density was measured according to the standard MKS BS EN 12127: 1998 yarn count according to the standard ISO 7211-5:1984 and MKS EN 1049-2: 2007 was used to determine the yarn density. A thermoplastic lockstitches reinforced tape for seam strengthening was used (Fig.1). The composition of the thermoplastic lockstitches reinforced tape is $100 \%$ PES. The thermoplastic interlining of the tape is a non-woven fabric with $45\left(\mathrm{~g} \cdot \mathrm{m}^{-2}\right)$ surface density, reinforced with stitches in a sewing direction. Seam samples without reinforcement and reinforced with a fused tape were prepared. The fusing process was performed at the temperature of $135^{\circ} \mathrm{C}, 3$ bar pressure for 13 seconds. All the samples were prepared with $1.2 \mathrm{~cm}$ seam allowance.

Table 1. Characteristics of fabrics used in test

\begin{tabular}{|c|c|c|c|c|c|c|c|c|c|c|}
\hline \multirow{2}{*}{$\begin{array}{l}\frac{0}{2} \\
\frac{0}{\pi} \\
\text { एँ }\end{array}$} & \multirow{2}{*}{ 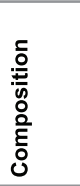 } & \multirow{2}{*}{  } & \multicolumn{2}{|r|}{ 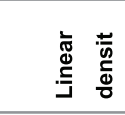 } & \multicolumn{2}{|c|}{ 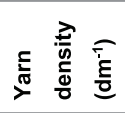 } & 단 & $\underbrace{\bar{E}}_{n}$ & \multirow{2}{*}{  } & \multirow{2}{*}{  } \\
\hline & & & $\underset{1}{3}$ & $\stackrel{\text { 亲 }}{上}$ & 3 & 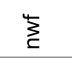 & $\frac{3}{0}$ & ${ }_{0}^{\frac{5}{0}}$ & & \\
\hline F1 & silk & plain & 3.2 & 3.2 & 470 & 400 & 0.007 & 0.007 & 0.52 & 28 \\
\hline F2 & PES & plain & 7.2 & 7.2 & 350 & 290 & 0.01 & 0.01 & 0.54 & 47 \\
\hline F3 & cotton & plain & 14 & 14 & 540 & 260 & 0.014 & 0.014 & 0.82 & 114 \\
\hline
\end{tabular}

The samples reinforced with fusible tapes were produced using three positions of a fixing fusible tape. In position 1 , (Fig.2.1) the thermoplastic tape on the seam allowance was

\footnotetext{
* Author address: Saška Golomeova, Faculty of Technology, Krste Misirkov 10, 2000 Štip, Macedonia

E-mail: saska.golomeova@gmail.com

The manuscript received: April, 18, 2017.

Paper accepted: May, 23, 2017.
} 
fused in a way that the seam allowance is completely covered with the tape. In position 2, (Fig.2.2) the thermoplastic tape is equally distributed at both sides of a stitching line, while in position 3 (Fig.2.3), only a few $\mathrm{mm}$ of the seam allowance is fused with the tape. A group of ISO standards (ISO 13934-2:2004 + ISO 13935-2:2004 + ISO 13936-1:2004) for the determination of the fabric strength, seam strength and seam slippage were used for seams testing. The samples were tested on ASDL Atlas tensile tester.



Figure 1. Thermoplastic lockstitches reinforced tape (T1)

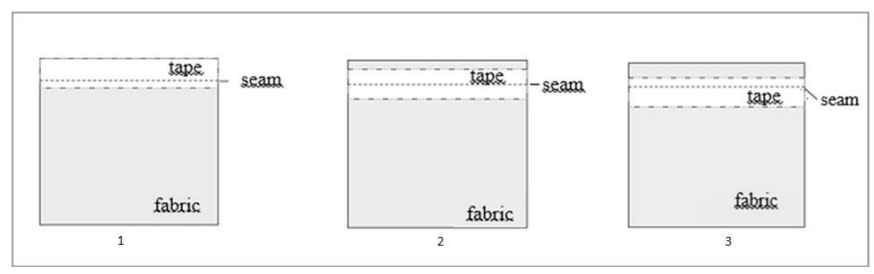

Figure 2. Thermoplastic stitched reinforced tape (T1) fused in three positions in the seam

\section{Results and Discussion}

The obtained results have shown that, with insertion of the thermoplastic stitched reinforced tape in the seam structure, generally the seam strength and efficiency are increased, while seam slippage decreased for all three fabrics. In the fusing process, substrate of interlining is fused onto the fabric by a thermoplastic polymer. One part of the polymer remains on the fabric surface, fuses the substrate and the fabric, and the other part of polymer migrates into the internal fabric structure through the interspaces of warp and weft yarns. Warp and weft fabric yarns are fused together, the fabric structure consolidated and yarn slippage resistance increases. The increase in the seam strength is due to the strengthening of the fabric structure in the seam area. The results for all three fabrics are shown in Fig.3 and Fig.4.

In all investigated cases it was found that the difference in the reinforced tape position in the seam influences at seams performance. In fabric F1, the seam slippage strength has the highest value when the tape is in position 2, the seam strength and seam efficiency have the highest value when the tape is in position 3. For the second fabric F2, the results show that the seam slippage strength has the highest value when the tape is in position 2 and the seam properties, seam strength and seam efficiency have the highest value when the tape is in position 1. In fabric F3, the seam slippage strength has the highest value when the tape is in position 1 while the seam strength and seam efficiency have the highest value when the tape is in position 2 .



Figure 3. Seam slippage strength and the seam strength with and without a thermoplastic stitched reinforced tape fused at three positions in the seam area for fabric F1 (a), fabric F2 (b), fabric F3 (c)

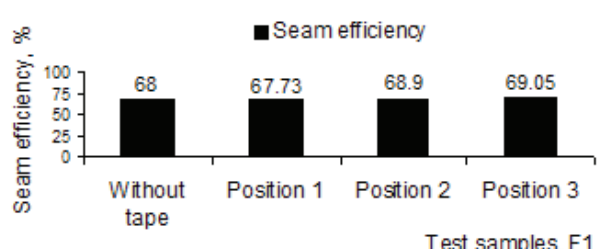

(a)

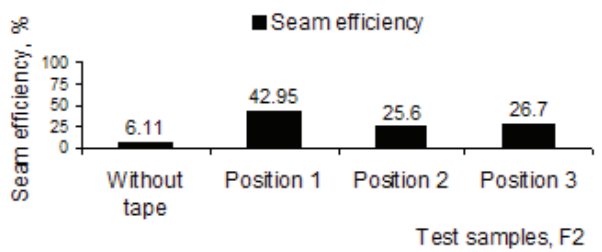

(b)



(c)

Figure 4. Seam efficiency with and without thermoplastic stitched reinforced tape fused in three positions in the seam area for fabric F1 (a), fabric F2 (b), fabric F3 (c) 


\section{Conclusion}

In this study, the effect of the thermoplastic stitched reinforced tape location in the seam, on the seam slippage, seam strength and seam efficiency was investigated. From the results obtained, we can conclude that with the insertion of the thermoplastic stitched reinforced tape (T1) in any position in the seam construction seam the slippage strength, seam strength and seam efficiency increase. The results have shown that the location of the fused tape has influence on the seam performance. When the tape is in position 2, at least one of the properties has the highest value.

\section{References}

[1] P. Brown, J. Rice, Ready to wear apparel analysis, Prentice Hall, New Jersey, 2001, p.30-120.

[2] J. Gersak, B. Knez, Reduction in thread strength as a cause of loading in the sewing Process, International Journal of Clothing Science and Technology, 3(4) (1991) 6- 12.

[3] B.U. Nergis, Performance of seams in garments, African Textiles, 1998, p. 29-31.

[4] R. Namiranian, S.S Najar, M.S Eteati, M.A. Manich, Seam slippage and seam strength behavior of elastic woven fabrics under static loading, Indian Journal of Fiber \& Textile Research, 39(3) (2014) 221-229.

[5] F.F.S. Ebrahim, Influence of Mechanical properties of Cotton Fabrics on Seam Quality, Journal of American Science, 8(5) (2012) 429-434.

[6] B. Murugesan, Analysis on Sewing Performance of Ring, Rotor, Airjet and DREF-3 Friction Spun Yarn Fabrics, Journal of Scientific \& Industrial Research, 73(8) (2014) 521-524.
[7] S.J. Kadolph, A.L. Langfoid, N. Hollen, J. Saddler, Textiles, Macmillan, New York, 1998.

[8] A.M. Seif, Investigating The Seam Slippage of Satin Fabrics, International Journal of Textile and Fashion Technology, 4(5) (2014) 1-10.

[9] ISO 13936-1:2004, Textiles. Determination of the slippage resistance of yarns at a seam in woven fabrics-Part 1: Fixed seam opening method, 2004, p. 1-7.

[10] E. Malciauskiene, Investigation of influence of fabric structure parameters on slippage resistance at a seam, Thesis, Department of Textile Technology, Faculty of Design and Technology, Kaunas, 2012.

[11] ISO 13935-2:1999, "Textiles - Seam tensile properties of fabrics and made up textile articles - Part 2: Determination of maximum force to seam rupture using the grip method", 1999, 1-7.

[12] C. Sundaresan, K.R. Salhotra, P.K. Hari, Strength reduction in sewing threads during high speed sewing in industrial Lockstitch machine part II: Effect of thread and fabric properties, International Journal of Clothing Science and Technology, 10(1) (1998) 64 -79.

[13] A. Gurarda, B. Meric, Slippage and Grinning Behavior Of Lockstitch Seams in Elastic Fabrics under Cyclic Loading Conditions, Tekstil ve Konfeksiyon, 20(1) (2010) 65-69.

[14] N. Pasayev, M. Korkmaz, D. Baspinar, Investigation of techniques decreasing the seam slippage in chenille fabrics (part 2), Textile research journal 81(20) (2011) 2075-2081.

[15] B.K. Behera, S. Chand, T.G. Singh, P. Rathee, Sewability of denim, International Journal of Clothing Science and Technology, 9(2) (1997) 128-140.

[16] B.K. Behera, S. Shakun, S. Snrabhi, S. Choudhary, Comparative assessment of low stress mechanical properties and sewability of cotton and cotton banana union fabric, Asian Textile Journal, 9(5) (2000) 49-56.

\section{Izvod}

\section{UTICAJ LOKACIJE TERMOPLASTIČNE TRAKE ZA OJAČAVANJE NA KARAKTERISTIKE ŠAVOVA}

Saška Golomeova ${ }^{1}$, Goran Demboski²

1 Tehnološki fakultet, Univerzitet "Goce Delčev"- Štip, Makedonija

2 Tehnološko-metalurški fakultet, Univerzitet "Sveti Ćiril i Metodije"- Skoplje, Makedonija

$U$ radu se ispituje uticaj lokacije termoplastične trake za ojačavanje na šavu, na klizanje šava, jačinu i efikasnost šava. Pripremljeni su uzorci bez ojačanja i sa ojačanjem sa $1,2 \mathrm{~cm}$ dodatka za šavove. Ojačanii uzorci imali su tri lokacije fiksiranja termoplastične trake. Dobijeni rezultati pokazuju da ojačavanjem strukture šava termoplastičnom trakom, uopšteno se povećavaju jačina i efikasnost šava, dok se klizanje šava smanjuje. Dobijeni rezultati, takođe, pokazuju da razlika u lokaciji ojačavajuće trake u strukturi šava, utiče na performanse šavova.
(STRUČNI RAD)

UDK 687.053.665:677.074.33

Ključne reči: šav, termoplastična traka za ojačavanje, konstrukcija šava 